Editorial

\title{
Assessing What Brexit Means for Europe: Implications for EU Institutions and Actors
}

\author{
Edoardo Bressanelli ${ }^{1}$ and Nicola Chelotti ${ }^{2}$ \\ ${ }^{1}$ Dirpolis Institute, Sant'Anna School of Advanced Studies, 56127 Pisa, Italy; E-Mail: e.bressanelli@santannapisa.it \\ 2 Institute of Diplomacy and International Governance, Loughborough University London, London, E20 3BS, UK; \\ E-Mail: n.chelotti@Iboro.ac.uk \\ * Corresponding author
}

Submitted: 30 December 2020 | Published: 27 January 2021

\begin{abstract}
With the signing of the EU-UK trade and cooperation agreement in December 2020, the configurations of Brexit have started to become clearer. The first consequences of the UK's decision to leave the EU have become visible, both in the UK and in the EU. This thematic issue focuses on a relatively under-researched aspect of Brexit-what the UK withdrawal has meant and means for the EU. Using new empirical data and covering most (if not all) of the post-2016 referendum period, it provides a first overall assessment of the impact of Brexit on the main EU institutions, institutional rules and actors. The articles in the issue reveal that EU institutions and actors changed patterns of behaviour and norms well before the formal exit of the UK in January 2020. They have adopted 'counter-measures' to cope with the challenges of the UK withdrawal-be it new organizational practices in the Parliament, different network dynamics in the Council of the EU or the strengthening of the Franco-German partnership. In this sense, the Union has-so far-shown significant resilience in the wake of Brexit.
\end{abstract}

\section{Keywords}

Brexit; Council of the EU; Court of Justice; European Parliament; institutional change; interest groups; negotiations; Norway; United Kingdom

\section{Issue}

This editorial is part of the issue "What Brexit Means for Europe: EU Institutions and Actors after the British Referendum," edited by Edoardo Bressanelli (Sant'Anna School of Advanced Studies, Italy) and Nicola Chelotti (Loughborough University London, UK).

(C) 2021 by the authors; licensee Cogitatio (Lisbon, Portugal). This article is licensed under a Creative Commons Attribution 4.0 International License (CC BY).

\section{Introduction}

With the deal between the European Union (EU) and the United Kingdom (UK) sealed on Christmas eve 2020, four and a half years after the British referendum, Brexit was completed. We finally know 'what Brexit means' and, although the implementation of the agreement will take time, the separation has been effective and neat, with the UK leaving the single market, and with an end to both freedom of movement and the jurisdiction of the Court of Justice of the EU (CJEU) over British laws.

The conclusion of the Brexit negotiations and the end of the transition period also provide the opportu- nity to assess what impact Brexit has had on the EU institutions and actors so far. As Tim Oliver once put it (2016), there has been relatively little focus on what 'Brexit means for the EU.' Research on Brexit abounds and has, instead, largely focused on issues such as its causes (e.g., Hobolt, 2016), its impact on British politics (e.g., Ford \& Goodwin, 2017) and the EU-UK negotiations (e.g., Martill \& Staiger, 2020).

Oliver's assessment remains largely true today, even if it can certainly be better qualified. Scholars have started to reflect on the future of EU integration without the UK using macro-theoretical approaches such as 'disintegration' or 'differentiated integration' (e.g., 
Schimmelfennig, 2018). In addition, several studies have focused on specific EU policy areas or discrete policies. Most notably, a thematic issue of Politics and Governance has endeavoured to assess 'EU policies after Brexit' (De Ville \& Siles-Brügge, 2019). Other book-length treatments of the impact of Brexit have normally included a section on Britain and another on the EU-with the latter focusing on both macro-models and sectoral policies (e.g., Diamond, Nedergaard, \& Rosamond, 2018).

This thematic issue aims to fill this gap in the literature on Brexit by asking what has changed for EU institutions and actors after the 2016 British referendum. It considers institutions broadly, including both 'institutional rules' and what may otherwise be called 'organisations.' It provides the first extensive treatment of the topic focusing on the main EU institutions (i.e., the European Council, the Council of the EU, the European Parliament, the CJEU), key institutional rules (i.e., agenda-setting, the ordinary legislative procedure) and relevant actors (i.e., interest groups). In so doing, the contributors to this thematic issue address not only specific questions about Brexit, but also on EU integration more generally.

Our vantage point hugely benefits from the fact that the Brexit period is finally concluded and Brexit is, as a consequence, less of a 'moving target' than it used to be when some early analyses of the EU institutional set-up were made (cf. Jensen \& Snaith, 2018, p. 255; see also Jacobs, 2018; Patel \& Reh, 2016). A first overall assessment, based on new empirical data and covering most (if not all) of the post-referendum period can, therefore, be attempted. To be sure, this remains, in many respects, still preliminary, and a more all-round impact assessment would require additional data, time, and research.

Finally, the thematic issue evaluates the real impact of Brexit rather than simply taking the UK out of the 'decision-making equation' (for a similar approach, see also De Ville \& Siles-Brügge, 2019). This allows most contributors to be less speculative in their conclusions and, the sophistication of counterfactuals notwithstanding (Huhe, Naurin, \& Thomson, 2020), to ground the Brexit impact on observable behaviour rather than past history and theoretical simulations.

\section{Before Brexit: Anticipatory Adaptation and Informal Change}

The thematic issue endeavours to observe change in norms and patterns of behaviour already as a result of the outcome of the British referendum of 23 June 2016, rather than just as a consequence of the formal withdrawal of the UK on 31 January 2020. The referendum set in motion a number of informal changes, which predated the formal exit of the UK from the EU three and a half years later.

The long preparation to Brexit has allowed the EU institutions to prepare the UK withdrawal and anticipate some of its likely consequences. As the EU did in not too dissimilar circumstances in the past-for instance, preparing to its 'mega' enlargement to Central and Eastern Europe (cf. Best, Christiansen, \& Settembri, 2008)-the Union and its institutions proved capable of foreseeing changes in their environment. 'Anticipatory adaptation' could be observed, for instance, in revising the order of the country taking up the rotating Presidency of the Council of the EU, which should have been assigned to the UK in the second half of 2017.

Contributions in the thematic issue highlight several instances when, following the 2016 referendum, EU institutions started to adopt 'counter-measures' to deal with the challenges of the UK withdrawal. The drivers of institutional adaptation are different-and would certainly deserve further theoretical exploration-but EU institutions and actors may seek to protect themselves from the 'malign' influence of a soon-to-be third country; they may fear the organizational consequences of withdrawal and seek minimizing potential disruptions; they may be guided by the willingness to 'punish' disintegration and prevent further exits. Whatever the reason, the EU has been able to prepare for the departure of a large member state, making the impact of its actual departure less onerous.

Johansson (2021)-by analysing networks in the Council of the EU-finds that the UK was less central in 2018 (after) compared to 2015 (before the referendum). Even if the UK only stopped attending the Council meetings in September 2019, behavioural dynamics and coalition patterns in the Council had already changed when the UK was still an active member state, much to the detriment of the UK itself. Focusing on the European Parliament, Bressanelli, Chelotti, and Lehmann (2021) track a declining influence of the UK delegation since 2017, although British Members (MEPs) remained in Parliament until January 2020. As they argue, large cross-party alliances are often formed in the European Parliament when the institution is 'under attack' or when its members seek to expand its powers: Such a grand coalition was, during the Brexit negotiations, meant to limit the role of the British MEPs.

Simoncini and Martinico (2021) present an interesting-if legally very contentious-case. This is the decision to dismiss the British Advocate General Eleanor Sharpston from her job, notwithstanding the fact that, according to a legal interpretation, this decision would violate EU law and put at risk the independence of the CJEU. The member states decided to terminate her mandate early-in theory, she should have served in the role until October 2021-and such a decision was implemented by the CJEU. In so doing, they treated the Advocate General as if she effectively represented the UK and dismissed her because "Brexit ought to mean Brexit" (Pech, 2020).

Finally, Coen and Katsaitis (2021) show that the UK business groups played a rather minor role in the meetings with the EU Chief Negotiator Michel Barnier, who actively engaged with stakeholders. As the prospect of UK membership in the single market waned and because 
of their diminished role in pan-European organisations, they targeted mainly the British government. Conversely, Barnier himself directed his attention to British public interest groups, which served to maintain the EU's legitimacy vis-à-vis a portion of the UK's public as well as EU nationals in the UK.

\section{After the UK Withdrawal: Leadership and Decision-Making}

If the British referendum already set in pace Brexitrelated changes, the UK formal withdrawal from the EU in early 2020 unleashed new, or reinforced pre-existing institutional dynamics. As Krotz and Schramm (2021) argue, Franco-German leadership became stronger with Brexit. This was due not only to the rules for qualified majority in the Council-with the new weights for the double majority, of states and population, favouring the medium and large member states-but mainly to the necessity of Franco-German leadership to overcome the existential crises of the EU, Brexit included.

A specific instance of the 'new' Franco-German leadership is provided in the field of financial services. Van Kerckhoven (2021) shows that France and Germany are seeking to shape a different agenda-in essence, a more stringent rule-based approach towards the financial industry-and gain a more prominent role in this sector post-Brexit. One of the earliest direct impacts of Brexit-i.e., the relocation of the EU agencies based in London to 'the continent'-rewarded Paris as the new site of the European Banking Authority, signposting the French assertiveness and willingness to create an EU-27 financial hub.

While rules and agenda-setting powers in financial services are arguably set to change, Copeland (2021) emphasises continuity over change in the field of social policy. Despite the extension of the ordinary legislative procedure, the decision-making mode in the field remains intergovernmental, with (some) member states pulling the brake to more radical developments. Even if the UK was not supportive of supranational developments, it was certainly not the only member state to share this attitude, making intergovernmentalism very likely to 'survive' post-Brexit.

\section{The Resilience of the Union}

Brexit was part of an impressive string of crises hitting the EU since 2010. As with other crises, the prospects for Europe were dire: Brexit was widely regarded as a threat to integration and a trigger for disintegration, with a domino effect boosting Eurosceptic parties and fuelling the demands for other 'exits.' This scenario has not materialized; if Brexit (and other crises) have demonstrated anything, this is the strong resilience of the Union.

Looking beyond the EU and its institutions, Brexit also acted-so far at least-as a deterrent rather than as a stimulus for change for non-member countries with close relationships to the EU. Fossum and Vigrestad (2021) look at Norway, a member of the European Economic Area. If the Norwegian option was soon ruled out as a model for the future EU-UK relationship, was Brexit instead a source of inspiration for Norwegians? Their analysis reveals that Norway re-assessed the costs and benefits of its relationship with the EU in the light of Brexit, but both parties and public opinion maintained their preference for the status quo, with the former keen to depoliticize the issue of European Economic Area membership.

The capacity of the Union to 'absorb' environmental shocks and adapt to challenging conditions should be duly acknowledged. As this thematic issue has shown, while it is still possible to argue that the impact of Brexit on the EU institutions and actors "should not be overstated" (Puetter, 2017, p. 249), this is so not just because the EU 'muddles through' from crisis to crisis, but also because its institutions and actors can be proactive, seeking to prevent major disruptions in their operations.

\section{Acknowledgments}

We would like to thank the editors of Politics and Governance and Dr. Niheer Dasandi for their support, and all contributors to the Thematic Issue for their cooperation in difficult times.

\section{Conflict of Interests}

The authors declare no conflict of interests

\section{References}

Best, E., Christiansen, T., \& Settembri, P. (2008). The institutions of the enlarged European Union: Continuity and change. Cheltenham: Edward Elgar Publishing.

Bressanelli, E., Chelotti, N., \& Lehmann, W. (2021). Managing disintegration: How the European Parliament responded and adapted to Brexit. Politics and Governance, 9(1), 16-26.

Coen, D., \& Katsaitis, A. (2021). Lobbying Brexit negotiations: Who lobbies Michel Barnier? Politics and Governance, 9(1), 37-47.

Copeland, P. (2021). The ordinary legislative procedure in a post-Brexit EU: The case of social Europe. Politics and Governance, 9(1), 69-78.

De Ville, F., \& Siles-Brügge, G. (2019). The impact of Brexit on EU policies. Politics and Governance, 7(3), 1-6.

Diamond, P., Nedergaard, P., \& Rosamond, B. (2018). The Routledge handbook of the politics of Brexit. London: Routledge.

Ford, R., \& Goodwin, M. (2017). Britain after Brexit: A nation divided. Journal of Democracy, 28(1), 17-30.

Fossum, J. E., \& Vigrestad, J. (2021). Is the grass greener on the other side? Norwegians' assessments of Brexit. Politics and Governance, 9(1), 79-89.

Hobolt, S. (2016). The Brexit vote: A divided nation, a 
divided continent. Journal of European Public Policy, 23(9), 1259-1277.

Huhe, N., Naurin, D., \& Thomson, R. (2020). Don't cry for me Britannia: The resilience of the European Union to Brexit. European Union Politics, 21(1), 152-172.

Jacobs, F. B. (2018). The EU after Brexit: Institutional and policy implications. Cham: Palgrave Pivot.

Jensen, M. D., \& Snaith, H. (2018). Brexit and the European Union: Hanging in the balance? In P. Diamond, P. Nedergaard, \& B. Rosamond (Eds.), Routledge handbook of the politics of Brexit (pp. 254-265). London: Routledge.

Johansson, M. (2021). Explaining cooperation in the Council of the EU before and after the Brexit referendum. Politics and Governance, 9(1), 5-15.

Krotz, U., \& Schramm, L. (2021). An old couple in a new setting: Franco-German leadership in the post-Brexit EU. Politics and Governance, 9(1), 48-58.

Martill, B., \& Staiger, U. (2020). Negotiating Brexit: The cultural sources of British hard bargaining. Journal of Common Market Studies. Advance online publication. https://doi.org/10.1111/jcms.13059

Oliver, T. (2016). What impact would a Brexit have on the EU? (Dahrendorf Analysis 2/2016). London: LSE IDEAS.

Patel, O., \& Reh, C. (2016). Brexit: The consequences for the EU's political system (UCL Constitution Unit Briefing Paper). London: UCL Constitution Unit.

Pech, L. (2020). The Schrödinger's advocate general. Verfassungsblog. Retrieved from https:// verfassungsblog.de/the-schroedingers-advocategeneral

Puetter, U. (2017). Brexit and the European Union's institutional balance: How member states and EU institutions adapt to decision-making. In F. Fabbrini (Ed.), The law \& politics of Brexit (pp. 247-265). Oxford: Oxford University Press.

Schimmelfennig, F. (2018). Brexit: Differentiated disintegration in the European Union. Journal of European Public Policy, 25(8), 1154-1173.

Simoncini, M., \& Martinico, G. (2021). A knot not to be cut? The legacy of Brexit over the CJEU. Politics and Governance, 9(1), 27-36.

Van Kerckhoven, S. (2021). Post-Brexit leadership in European finance. Politics and Governance, 9(1), 59-68.

\section{About the Authors}
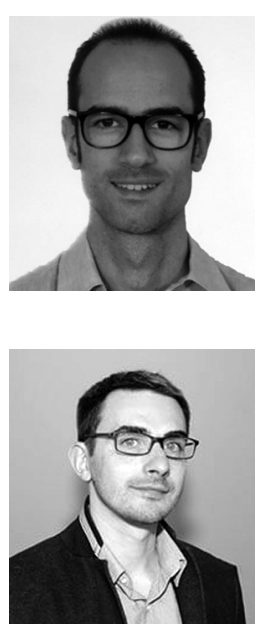

Edoardo Bressanelli is 'Montalcini' Assistant Professor in Political Science at the Sant'Anna School of Advanced Studies in Pisa, Italy. Before returning to Italy, Edoardo was a Senior Lecturer at King's College London, where he remains affiliated as a Visiting Senior Research Fellow. His research on EU institutions, parties and decision-making has been published in journals like Comparative Political Studies, the European Journal of Political Research, European Union Politics, the Journal of European Public Policy, among others.

Nicola Chelotti is Lecturer in Diplomacy and International Governance at Loughborough University London. Previously, he held academic posts at University College London and the London School of Economics and Political Science. His research interests focus on negotiations, diplomacy and regional/international organizations, the EU particularly. His research has been published in journals like the British Journal of Politics and International Relations, Cooperation and Conflict and West European Politics, among others. 